thorized and directed to transfer and deliver to the historical, memorial, and art department such of the public archives as are designated in the preceding section, except such as in the judgment of the executive council should be retained longer in the respective offices, and the curator is authorized to receive the same.

Sec. 20. Removal of Originat.

After any public archives have been received into the division of public archives by the curator, they shall not be removed from his custody without his consent, except in obedience to a subpoena of a court of record or a written order of the officer from whose office they were received.

Sec. 21. Certified Copres-Fees.

Upon request of any person, the curator shall make a certified copy of any document contained in said archives, and when such copy is properly authenticated by him it shall have the same legal effect as though certified by the officer from whose office it was obtained or by the secretary of state. Said curator shall charge and collect for such copies the fees allowed by law to the secretary of state for such ccrtified copies, and all such fees shall be turned into the state treasury.

Sec. 22. Bonvs.

Bonds of the state librarian, the law librarian, and the curator shall be approved by the board.

Sec. 23. Approphiations.

There is hereby appropriated annually from any money in the state treasury not otherwise appropriated, for the use of the state library, and the historical, memorial, and art department, as follows:

1. Two thousand dollars $(\$ 2,000.00)$ for the purchase of books and periodicals and for other uses deemed necessary to the upbuilding of the medical section, and for the purchase and transmission of material and information to the physicians and surgeons of the state.

2. Six thousand dollars $(\$ 6,000.00)$ for the use of the law section and the legislative reference bureau.

3. Six thousand dollars $(\$ 6,000.00)$ for the use of the general section.

4. Six thousand dollars $(\$ 6,000.00)$ for the use of the historical, memorial, and art department.

\title{
THE FIRST OF IOWA CONSERVATIONISTS
}

Theodore S. Parvin made a name in early Iowa that stands out in every view the founders took for better things. He served in a score of public and fraternal offices, but at whatever job his service was never petty. His vision was clearer than that of any other public official of his time, and his visions often were registered in documents prepared in whole or in part by him, 
issucd with or without credit to him by chief executives and lesser functionaries. No one has tried to trace his every influence. No one need be surprised in any field of worthy public endeavor to find his mark upon its earlier records.

Mr. Parvin once served as register of the State Land Office. Reporting December 1, 1857, on lands then owned by the state, he accounted for those at the seat of government. It is in this connection as set out herewith that he wrote of sparing the trees - the earliest conservation utterance we lave ericountered of an Iowa public man.

\section{FROM A REPOR'T OF THE REGISTER OF THE STATE LAND OFFICE, DECEMBER 1, 1857}

SEAT OF GOVERNMENT

The General Assembly by an act, entitled " $\Lambda \mathrm{n}$ Act to relocate the Scat of Government," approved January 25th, 1855, among other provisions made it the duty of the Commissioners to relocate the Seat of Government of the State, "to obtain as much land as is necessary for the Capitol Buildings, and also any and all grants and donations of land and town lots, witlin their power, to the State."

The Commissioners relocated the Seat of Government in this City, (Des Moines) and in accordance with the provisions of the act aforesaid, "obtained donations of lands and lots," and took "proper conveyances" to the State, of the following lands and town lots, viz:

CAPTTOL SQUARF:

Bounded and described, "Commeneing at a point, No. sixty-eight degrees $\mathbf{E}$. two chains and eighty-six and one half links from the centre, comer of section three, 'T. seventy-eight $N$, of $R$. twenty-four $W$. of the fifth principal meridian; thence $N$. seventy-four degrees thirty seconds E. six hundred and forty feet to a stone at the N. E. corner of Capitol Square, of the State of Iowa; thence S. fifteen degrees thirty seconds E. six hundred and eighty-two feet to a stone, at the S. E. corner of said Square; thence S. seventy-four degrees thirty minutes W. six hundred and forty feet, to a stone at the S. W. corner of said Square; thence N. fifteen degrees thirty minutes W. six hundred and eighty-two feet, to a stone at the N.W. corner of said Square, or place of beginning-containing ten acres and two hundredths of an acre, more or less." Conveyed by William A. Scott and Harrison Lyon, to the State of Iowa, April 28th, 1856, and Recorded in Book I., page eighty-six of the Polk County Records.

The second tract is conveyed by Thos. R. Brooks and Wilson $A$. Scott, on the 29th day of $\Lambda$ pril, 1856 , and recorded in the same Book, page eighty-seven, described as follows, viz: 
"Commencing at a point, $S$. thirty-two degrees thirty minutes W. one and sixty-five hundredths chains from the N.W. corner of the S.W. quarter of section two $T$. seventy-eight $N$. of $R$. twenty-four $W$.; thence $N$. seventy-four degrees thirty scconds $E$. six hundred and eighty feet to a stone; thence $S$. fifteen degrees thirty seconds $E$. three hundred and sixty feet to a stone; thence $S$. seventy-four degrees thirty seconds W. six hundred and eighty feet to a stone; thence $N$. fifteen degrees thirty seconds $W$. three hundred and sixty feet to the place of beginning-containing five and sixty-one hundredths acres, more or less."

Besides these two conveyances, J. A. Williamson and 'T. A. Walker, executed a Bond on the same day conditioned to convey to the State, two acres and nineteen hundredths, described as follows: "Beginning at a point $N$. eighteen degrees thirty-seven seconds $E$. If rom the $N$. $E$. corner of Capitol Square, distant one thousand five hundred and fiftyfour feet; thence $N$. fifteen degrees $W$. three hundred and eighteen feet; thence $N$. seventy-five degrees $F$, three hundred fect; thence $S$. fifteen degrees E. three hundred and eighteen feet; thence S. seventyfive degrees $W$. three hundred feet to the place of beginning-two and nineteen hundredths acres." This Bond is not recorded, but filed in the Secretary's office.

All of said Lands and Town Lots are situated in the City of Des Moines, upon beautiful wooded cminences, and the policy of the State should be to "spare the trees," protect and improve the grounds by a good, substantial fence, and otherwise, and guard against that vandalism which pervades so generally in this State to destroy, that the succeeding generation may have something to do in repairing their ravages. Better, far better, at less labor and expense, preserve the beautiful groves of native growth, than in after years expend greater sums to replace them.

T. S. PARVIN, Register.

\section{CURATOR OF HISTORICAL DEPARTMENT AS TRUSTEE OF SPIRIT LAKE MASSACRE MEMORIAI, AND GROUNDS}

Mr. E. R. Harlan, Curator,

Historical Department.

Dear Mr. Harlan:

The Executive Council at a meeting held August 10, 1921, adopted a resolution as follows:

Whereas, Chapter 333, Acts of the Thirty-seventh General Assembly provides for the custody of historic grounds by the office of the Curator of the Historical Department, and

Whereas, The Spirit Lake Massacre Monument and Grounds, until the recent death of Abbie Gardner Sharp were by courtesy maintained by Mrs. Sharp and are now without direct custody and oversight, and

Whereas, Among other things, it is necessary that the grounds be 
kept in a sightly condition and that the bronze tablets, through the ignorance of someone, have been coated with a preparation of black paint which should be skillfully removed and the monument and grounds hereafter maintained perpetualiy in a way appropriate to the spirit in which they were provided and dedicated; therefore

Resolved, That the Curator of the Historical Department be and he hereby is, subject to proper provisions approved in writing by the Board of Trustees of the Historical Department of Iowa, directed to assume and continue control and responsibility as Trustee of the State of Iowa for said monument and grounds.

The above resolution was unanimously adopted by the Council.

Yours very truly,

R. E. JOHNSON, Secretary.

\section{GEORGIA AND IOWA MARRIAGES, 1864}

World annals teem with instances of attachments of the sons and daughters of victors with sons and daughters of vanquished. Iowa and Georgia had their examples as evidenced in the marriage records of Clarke County, Iowa, by the returns following: FIRST RECORD BOOK OF MARRIAGES OF CLARKE COUNTY, IOWA

Office Provost Marshall

Rome Georgia, 15th Aug. 1864.

To Any Chaplain in the Armies of the United States.

\} GREETIN G.

By virtue of Authority in me vested, I hereby authorize you to unite in the Holy Bands of Wedlock, Pvt John Reynolds, 39th Inf Iowa Vol.g\& Miss Elizabeth Wallace, of Floyd Co. Ga.

By Order of

Brig Gen Wm. Vancleave

Josiah Rollins

Capt. \& Prvt Marshal

Floyd County, Ga., 17th $\Lambda$ ug 1864

By virtue of authority in me vested, Mr John Reynolds, Member of Company D 39th Iowa Infantry Vol \& Miss Elizabeth Wallace of Floyd County Georgia, have this day been united in the Holy Bands of Wedlock.

Eld. A. H. Chase

We the undersigned members of Company D 39th Iowa Infty Vol hereunto subscribe our names as witnesses to the above.

A. E. Chase

William L. Chaney

John C. Johnson 
Copyright of Annals of Iowa is the property of State of Iowa, by \& through the State Historical Society of Iowa and its content may not be copied or emailed to multiple sites or posted to a listserv without the copyright holder's express written permission. However, users may print, download, or email articles for individual use. 